Article

\title{
Temporal Distribution of Finfish and Shellfish in Payra River: Relationship with Climatological Changes, Ecological Pollu- tion, and Threat Assessment
}

Md. Asikur Rahaman Rahat ${ }^{1}$, Nitai Roy ${ }^{2}$, Md. Rased Khan Manon ${ }^{3}$, Md. Rahamat Ullah', M. Muhsinul Islam ${ }^{3}$, Md. $^{1}$ Tareq Rashid ${ }^{3}$, Khandakar Rakibul Hasan ${ }^{3}$, Suprakash Chakma ${ }^{4}$, and Md. Arifur Rahman ${ }^{1 *}$

1 Department of Fisheries Biology and Genetics, Faculty of Fisheries, Patuakhali Science and Technology University, Dumki, Patuakhali-8602; asik.rahat5@gmail.com (M.A.R.R); rahamatullah096@gmail.com (M.R.U); marahman@pstu.ac.bd (M.A.R)

2 Department of Biochemistry and Food Analysis, Faculty of Nutrition and Food Science, Patuakhali Science and Technology University, Dumki, Patuakhali- 8602; ncroy87@gmail.com (N.R)

3 Faculty of Fisheries, Patuakhali Science and Technology University, Dumki, Patuakhali- 8602; rased.khan2274@gmail.com (M.R.K.M); muhsin.islam317@gmail.com (M.M.I); rashidtareq393@gmail.com (M.T.R); khandakarpstu3847@gmail.com(K.R.H)

4 Department of Fisheries Technology, Faculty of Fisheries, Patuakhali Science and Technology University, Dumki, Patuakhali- 8602; sup.fst@pstu.ac.bd (S.C)

* Correspondence: marahman@pstu.ac.bd; Tel.: +88-01783-401582

\begin{abstract}
The Payra River is one of the large coastal rivers in Bangladesh which supports incredible fish species and has been affected by extensive human disturbance due to huge fishing pressure. The present study provides information about the temporal diversity of finfish and shellfish concerning climatological variables and ecological pollution along with threat assessment in the Payra River, Patuakhali. During the entire study, a total of 61 fish species including 56 finfish and 5 shellfish species were recorded under 22 families belonging to 11 orders. The order-wise fish species availability showed that the Perciformes $(29.49 \%)$ was the dominant order based on species richness. Among them, 4 endangered, 6 vulnerable, 4 near threatened, 42 least concern, and 5 data deficient species were found. During the study period, the average Shannon-Weaver diversity index value was (3.33 \pm 0.12$)$ indicates a good spread of fish population in the Payra river. Average Margalef richness index value was found (7.60 \pm 0.32$)$, Pielou's evenness index $(0.48 \pm 0.05)$, and Simpson dominance index $(0.93 \pm 0.02)$ in Payra river. Dominance and Richness index value indicates clear water environment to slight pollution in the Payra river. Ten different kinds of fishing gears were identified under 3 major groups including 5 nets, 3 hooks and lines, and 2 traps. The phytoplanktonic genus and species revealed moderate pollution. Canonical correspondence analysis ordination plot showed that rainfall was the most influencing driving force among the meteorological parameters. The cluster analysis based on the Bray-Curtis similarity matrix showed that the winter season formed a separate cluster. In the recapitulation, the Payra River is a highly productive system that provides a favorable environment for a large variety of finfish and shellfish species assemblages. Findings of the conducted study are expected to be helpful for the respective researchers, policymakers, managers, and conservationists for the sustainable management of this water body and the interconnected surrounding neighboring countries.
\end{abstract}

Keywords: finfish; shellfish; biodiversity indices, ecological pollution; Payra river

\section{Introduction}

Bangladesh is endowed with huge and diverse fishing resources as a result of its extensive riverine network like the Ganges (Padma), Brahmaputra (Jamuna), and Me- 
ghna Rivers. Estuaries are dynamic habitats marked by considerable swings in environmental conditions because they are the meeting location of freshwater from rivers and saltwater from the sea [1]. Estuaries are utilized as nursery grounds by many marine creatures, and they spend part of their life cycle in both fresh and saltwater. Coastal rivers are an important natural ecosystem in Bangladesh [2], as they provide natural spawning grounds and nursery grounds for many commercially important species of aquatic biota, particularly Hilsa (Tenualosa ilisha), and they account for a significant portion of the country's fisheries production. As a means of livelihood, more than $11 \%$ of Bangladesh's entire population is employed in this sector, both full-time and part-time [3]. Overexploitation, siltation, industrial pollution, use of synthetic monofilament nets, overdosing of fertilizers and insecticides in agricultural lands, and ecological disturbances are all contributing to a decline in fish output [4-6]. Changing land use, modifying river flow regimes, riparian and physical habitat loss, water pollution, alien species invasions, and heavy exploitation of fish stocks are only a few of the anthropogenic disturbances that have a significant impact on riverine ecosystems and fisheries. As a result, substantially more freshwater species than terrestrial or marine species in the same taxonomic groups are threatened or endangered [7]. Fish is important from an ecological standpoint not only because of its economic importance but also because it is sensitive to environmental changes and reflects a wide range of tolerance at the community level [8]. As a result, fish assemblages have been widely employed as biological indicators to quantify and evaluate the amount of river and stream degradation and health [9]. The Payra River is a body of flowing water that flows to a lower level in a channel on land in Bangladesh, eventually falling into the Bay of Bengal as the Burishwar River. This river has a unique aquatic habitat with a wide range of plants, fish, and other biological types [10]. Throughout the year, the river has a somewhat turbulent water flow. It is one of the most important coastal rivers in Bangladesh's Hilsha migration route and the small hilsha (Jhatka) is most plentiful in this river from January to March [11]. The river, which was previously a shelter for brood fishes, has now become rather unsafe due to anthropological factors. According to locals, the diversity of fish species in the Payra River is gradually dwindling due to overfishing, the use of harmful fishing gear (Set bag net), and other issues. Biodiversity is frequently used to assess the state of a biological system's health [12]. Previously, Islam et al. [10] studied the Payra River's fish composition. They did not, however, work on the fish-environment interaction. The current study aimed to determine the river's finfish and shellfish diversity and temporal distribution, as well as the relationship between fish and physicochemical and environmental changes, as well as the level of ecological contamination in Payra. The basic information gathered during this study will be useful in developing and managing the Payra River's development and management program.

\section{Materials and Methods}

\subsection{Study Area}

The Pandav point is the confluence of the Pangasia, Tetulia, and Payra rivers. The Payra river has a large water circulation area. The current study was conducted monthly in the Payra river at Pandav point in the Patuakhali district of the Barisal division from July 2018 to June 2019 (Figure 1). 


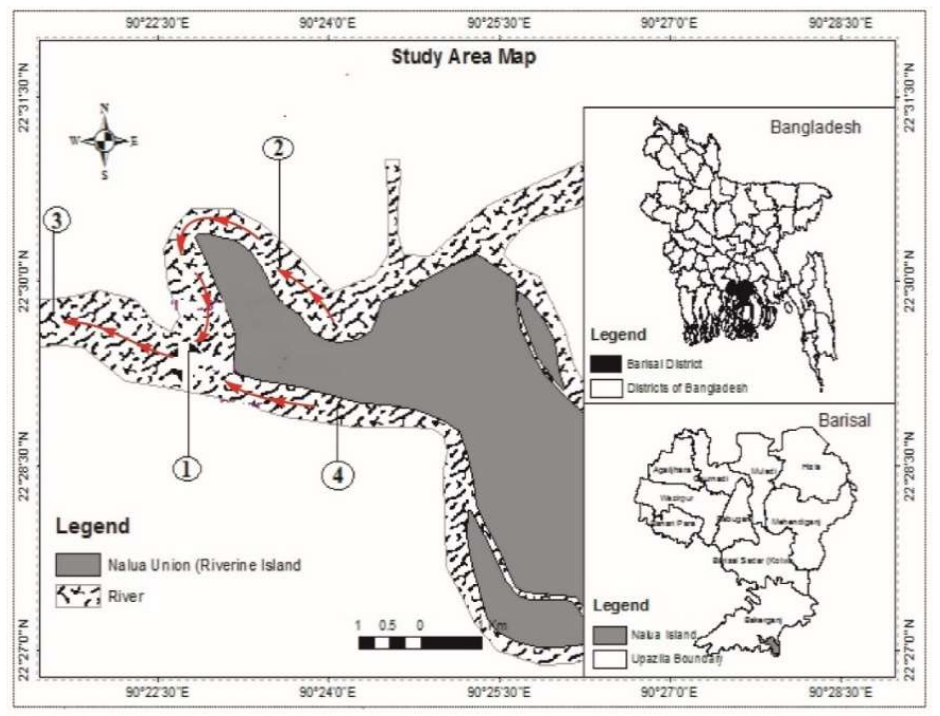

Figure 1. The map shows a reference of the record and geographical location of the study area in Payra River, Patuakhali. The red arrows in the map indicate the direction of water flow in the Payra river system. 1) Karkhana river (Pandab point)- Latitude $\left(22^{\circ}\right.$ $\left.29^{\prime} 40.31^{\prime \prime} \mathrm{N}\right)$ and Longitude $\left(90^{\circ} 21^{\prime} 23.10^{\prime \prime} \mathrm{E}\right)$; 2) Karkhana river- Latitude $\left(22^{\circ} 29^{\prime} 18.23^{\prime \prime} \mathrm{N}\right)$

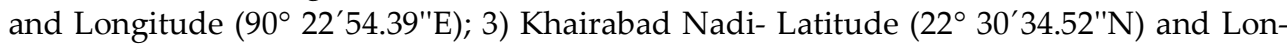
gitude $\left(90^{\circ} 21^{\prime} 24.88^{\prime \prime} \mathrm{E}\right)$; and 4$)$ Bighai river- Latitude $\left(22^{\circ} 48^{\prime} 45.25^{\prime \prime} \mathrm{N}\right)$ and Longitude $\left(90^{\circ}\right.$ $\left.21^{\prime} 14.17^{\prime \prime} \mathrm{E}\right)$.

\subsection{Finfish and Shellfish Data Collection}

We worked with both primary and secondary data in this investigation. Primary data was gathered from local fishermen in the area next to our study area who rely on fishing for a living. Sampling was done on monthly basis based on questionnaire interviews with fishers and a market survey of the adjacent landing center of Pandav point, Payra River area for fish diversity assessment. The key informant interviews were also performed for comprehending the undergoing threat assessments in the study area (Figure 2). The species to species data was recorded as species $/ \mathrm{kg}$ fish. The species were identified based on FishBase [13]. The sampling was done encompassing four seasons: monsoon (July-September), post-monsoon (October-November), winter (December-February), and summer (March-April).

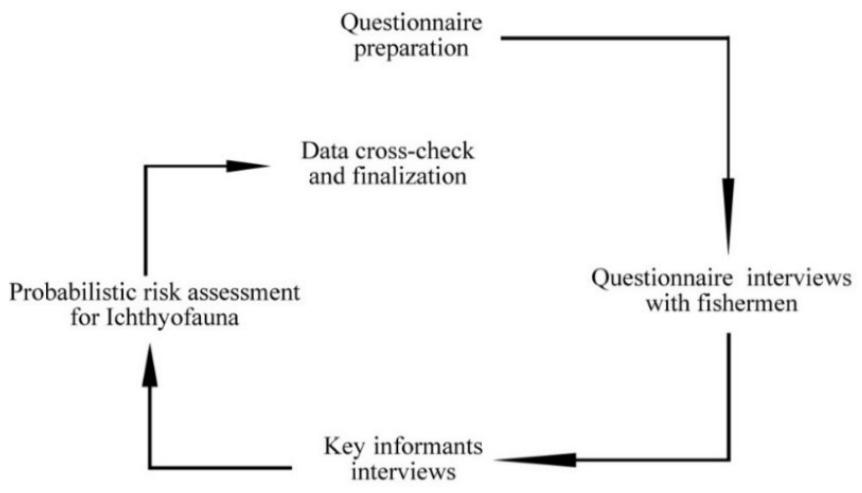

Figure 2. Data collection methods from fishermen to trace probabilistic risk factors and decision-making after validation. 


\subsection{Collection of Meteorological Parameters}

The meteorological data of rainfall $(\mathrm{mm})$, air temperature $\left({ }^{\circ} \mathrm{C}\right)$, photoperiod (hrs./Day), and relative humidity (\%) were collected from Bangladesh Meteorological Department (BMD), Patuakhali station.

\subsection{Pollution Level Based on Phytoplanktonic Species}

Phytoplankton found in water bodies represents the average ecological condition and can thus be used as a water quality indicator $[14,15]$. The Palmar's algal genus and species pollution index were used to determine the pollution level in the Payra river throughout the investigation (Table 1).

Table 1. Algal genus and species-based Pollution Index.

\begin{tabular}{lclc}
\hline Genus & Pollution Index & Algal species & Pollution Index \\
\hline Anacystis & 1 & Ankistrodesmus falcatus & 3 \\
Ankistrodesmus & 2 & Arthrospira jenneri & 2 \\
Chlamydomonas & 4 & Chlorella vulguris & 2 \\
Chlorella & 3 & Cyclotella meneghiniana & 2 \\
Closterium & 1 & Euglena gracilis & 1 \\
Cyclotella & 1 & Euglena viridis & 6 \\
Euglena & 5 & Gomphonema parvulum & 1 \\
Gomphonema & 1 & Melosira varians & 2 \\
Lepocinclis & 1 & Navicula cryptocaphala & 1 \\
Melosira & 1 & Nitzschia acicularis & 1 \\
Micractinium & 1 & Nitzschia palea & 5 \\
Navicula & 3 & Oscillatoria chlorine & 2 \\
Nitzschia & 3 & Oscillatoria limosa & 4 \\
Oscillatoria & 5 & Oscillatoria princeps & 1 \\
Pandorina & 1 & Oscillatoria putrid & 1 \\
Phacus & 2 & Oscillatoria tenuis & 4 \\
Phormidium & 1 & Pandorina mormorum & 3 \\
Scenedesmus & 4 & Scenedesmus quadricauda & 4 \\
Stigeoclonium & 2 & Stigeoclonium tenue & 3 \\
Synedra & 2 & Synedra ulna & 3 \\
\hline & & &
\end{tabular}

N.B. Palmer [14] used numerical values to classify pollution, with 0-10 indicating no organic pollution, 10-15 indicating moderate pollution, 15-20 indicating possible high organic pollution, and 20 or more indicating confirmed high organic pollution.

\subsection{Statistical Analysis}

In the present investigation, the Shannon-Weaver diversity index $\left(\mathrm{H}^{\prime}\right)$, Margalef species richness index (d), Pielou's evenness index $\left(\mathrm{J}^{\prime}\right)$, and Simpson dominance index (c) were employed to evaluate finfish and shellfish diversity and pollution levels [8,16-18]. The Shannon-Weaver diversity index $\left(\mathrm{H}^{\prime}\right)$ and Margalef species richness index $(\mathrm{d})$ value was used to determine the ecological state of the Payra river $[19,20]$. To see if there was a significant variation in environmental variables and diversity indices between seasons, a 
one-way analysis of variance (ANOVA) was employed. SPSS software version V25.0 (Statistical Package for Social Sciences) was used for the ANOVA test. A Games-Howell nonparametric post hoc analytic approach was used to compare all conceivable group differences. The software PAST (Paleontological Statistics) version 3.0 was used to perform all of the multivariate analyses. The association between species assemblage composition and environmental variables was investigated using Canonical correspondence analysis (CCA). ArcGIS 10.0 software was used to map the study region and depict study/sampling locations using a global positioning system (GPS).

\section{Results and Discussion}

\subsection{Environmental Parameters of the Investigated Area}

Fish species in open water bodies that are completely reliant on natural feeds (e.g., phytoplankton and zooplankton) are highly sensitive and respond quickly to environmental changes. Environmental characteristics were employed in this study to assess the impact on finfish and shellfish diversity. Table 2 shows the major four environmental characteristics that have been observed to influence the fish assemblage in the Payra river. The maximum atmospheric temperature was recorded $29.61 \pm 0.45$ in monsoon and a minimum of $21.01 \pm 1.46$ in winter with an average value of $26.93 \pm 3.95$. Besides uppermost photoperiod (hrs./day) $7.82 \pm 0.56$ was measured in winter and the lowermost $5.31 \pm 0.95$ in monsoon with an average value of $6.78 \pm 1.48$. On the other hand, the highest rainfall $(\mathrm{mm})$ $40.06 \pm 53.59$ was recorded in monsoon and a minimum of $3.41 \pm 4.35$ in post-monsoon with a mean value of $13.18 \pm 28.39$. In addition, higher relative humidity (\%) $86.25 \pm 2.63$ was recorded in the monsoon and a minimum of $71.00 \pm 2.81$ in winter with an average value of 78.25 \pm 6.46 . All climatological variables showed significant differences $(p<0.05)$ between seasons and relationships between climatological parameters are shown in Figure 3. Environmental factors affecting fish communities at local and regional sizes are well understood [7,21,22]. Regional factors such as rainfall, humidity, and air temperature, however, do account for some of the difference [23-26]. As a result, our findings back up earlier research that has found that local and regional factors play a role in determining diversification patterns $[27,28]$.

Table 2. The climatological parameter's value was collected from Bangladesh Meteorological Department (BMD), Patuakhali station for the study area in different seasons.

\begin{tabular}{llllll}
\hline Climatological parameters & \multicolumn{1}{c}{ Monsoon } & Post-monsoon & Winter & Summer & $p$-value \\
\hline Air temperature $\left({ }^{0} \mathrm{C}\right)$ & $29.61^{\mathrm{ab} \pm 0.45}$ & $27.06^{\mathrm{ac}} \pm 2.81$ & $21.01^{\mathrm{d}} \pm 1.46$ & $29.28^{\mathrm{b}} \pm 1.83$ & 0.001 \\
Photoperiod $($ hrs. $/$ day) & $5.31^{\mathrm{cd}} \pm 0.95$ & $6.04^{\mathrm{ac}} \pm 0.35$ & $7.82^{\mathrm{ab}} \pm 0.56$ & $7.49^{\mathrm{b}} \pm 1.70$ & 0.093 \\
Rainfall $(\mathrm{mm})$ & $40.06^{\mathrm{a}} \pm 53.59$ & $3.41^{\mathrm{b}} \pm 4.35$ & $5.29^{\mathrm{b}} \pm 9.16$ & $3.84^{\mathrm{b}} \pm 3.71$ & 0.342 \\
Relative humidity $(\%)$ & $86.25^{\mathrm{a}} \pm 2.63$ & $77.89^{\mathrm{bc}} \pm 3.03$ & $71.00^{\mathrm{d}} \pm 2.81$ & $77.88^{\mathrm{c}} \pm 4.83$ & 0.007 \\
\hline
\end{tabular}

The $p$-value indicates significance at $p<0.05$ (One-way ANOVA). 

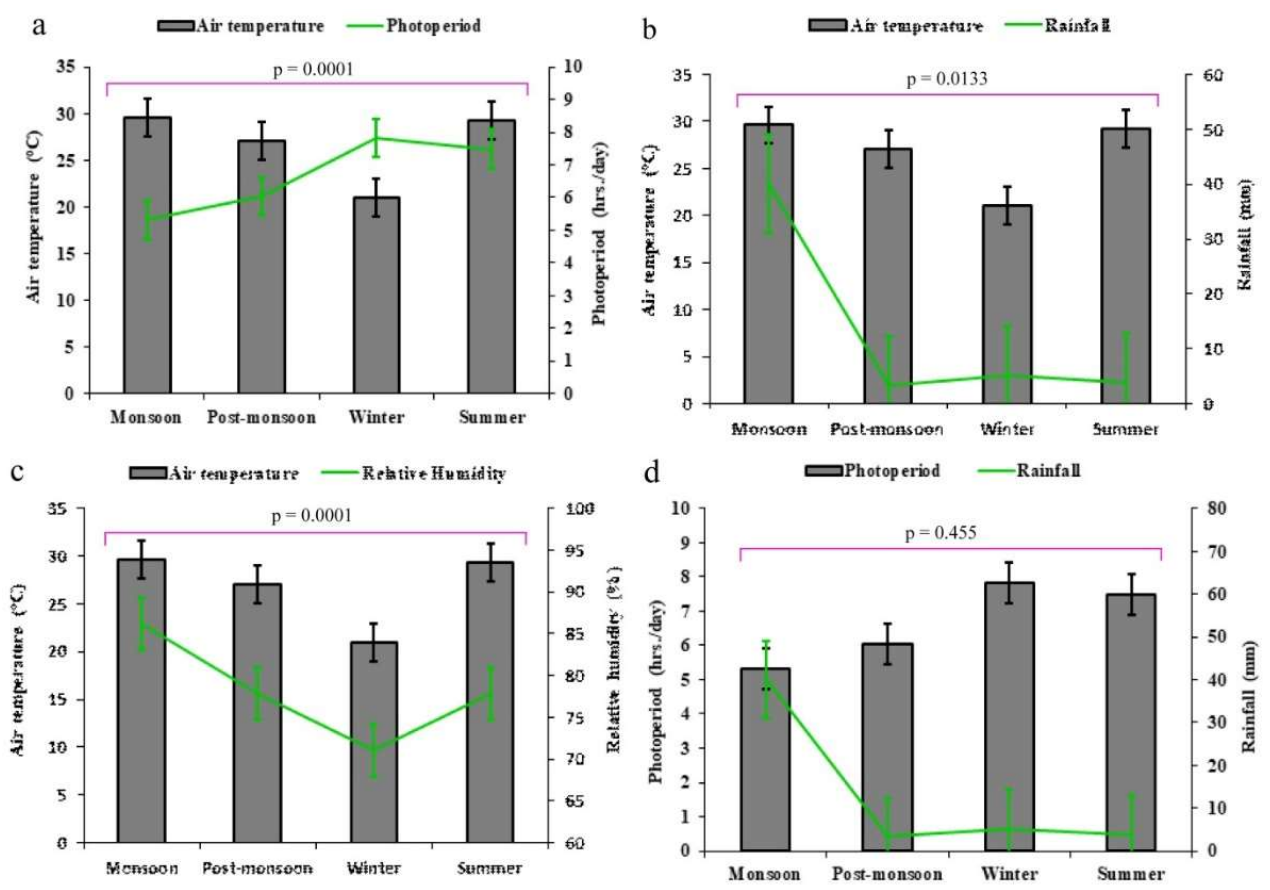

Figure 3. Relationships between climatological parameters during the study period a) Relationship between air temperature $\left({ }^{\circ} \mathrm{C}\right.$ ) and photoperiod (hrs./day); b) air temperature $\left({ }^{\circ} \mathrm{C}\right)$ and rainfall $\left.(\mathrm{mm}) ; \mathrm{c}\right)$ air temperature $\left({ }^{\circ} \mathrm{C}\right)$ and relative humidity $(\%)$, and d) photoperiod (hrs./day) and rainfall $(\mathrm{mm})$. The $p$-value indicates significance at $p<0.05$ (Two-way ANOVA).

\subsection{Finfish and Shellfish Biodiversity}

\subsubsection{Order Based Fish Species Availability}

As a coastal river, the Payra supports a diverse range of fish species belonging to many orders and families. In the fishing region, about 61 species were reported, including 56 finfish and five shellfish species, divided into 22 families and 11 orders. The order basis fishes species availability showed that Perciformes (29.49\%) was dominant order followed by Cypriniformes (26.23\%), Siluriformes (11.48\%), Decapoda (8.20\%), Clupeiformes (6.56\%), Mugiliformes (6.56\%), Anguilliformes (3.28\%), Osteoglossiformes $(3.28 \%)$, Tetraodontiformes (1.64\%), Beloniformes (1.64\%) and Cyprinodontiformes $(1.64 \%)$. Tetraodontiformes, Belonifirmes, and Cyprinodontiformes are the least ordered and found in the least amount in contrast to other families, according to this study (Figure 4a). Cyprinidae was the most abundant family throughout the research period, with 15 species, followed by Gobiidae, Channidae, Mugilidae, Bagridae, Clupeidae, Schilbeidae, and Notopteridae. According to IUCN [29] among the 61 finfish and shellfish species 4 endangered, 6 vulnerable, 4 near threatened, 42 least concern, and 5 data deficient species were found (Figure $4 \mathrm{~b}$ ). We also recorded 19 species that have yet to be assessed for conservation status by the International Union for Conservation of Nature (IUCN) (Figure 4c). During the study, a total of 61 fish species were found in the Payra river (Table 3) while Hossain et al. [4] reported 53 species in the Meghna river estuary, Mohsin and Haque [30] reported 56 fish species in the Mahananda river, Chakraborti, and Mirza [31] reported 66 fish species in the Someswari river, Tongnunui et al. [32] found 79 species in Mae Klong River, and Islam et al. [10] enlisted 52 species in Payra river. Our investigation showed more or less identical results for species distribution based on all of these data. Long-term changes in hydrological and climatic conditions are 
to blame for the loss of species diversity. Another factor for poor species diversity is fishermen's long-term usage of ESBN nets, which catch everything from tiny aquatic invertebrates to giant fish. Payra River, as a coastal river, has a considerable fishery variety and is one of Bangladesh's most species-rich coastal rivers, and it requires good management to re-establish its prior species richness.

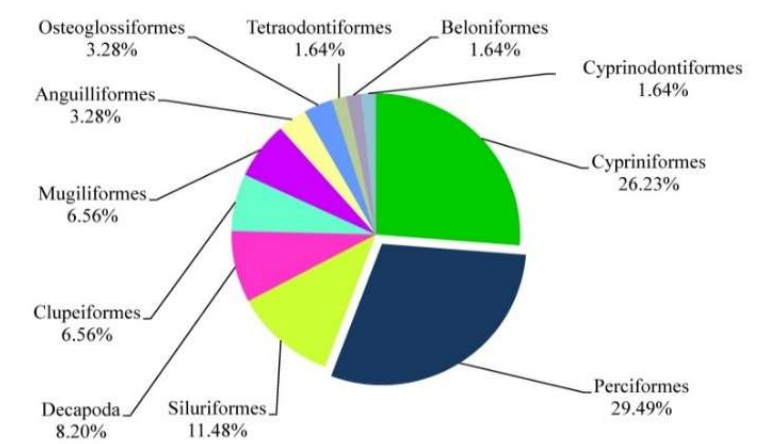

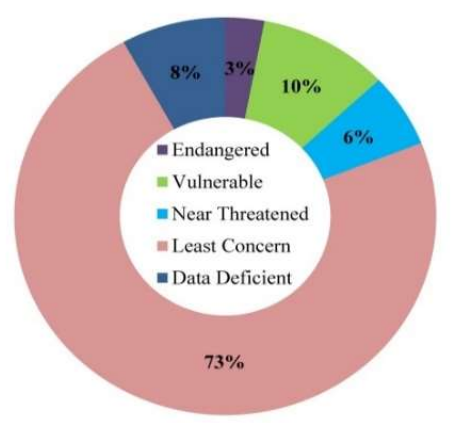

(b)

(a)

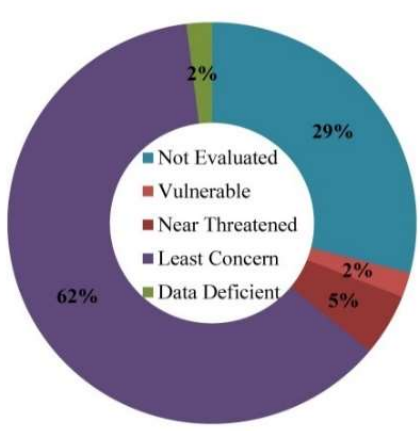

(c)

Figure 4. (a) Order-based fish species available in the study area, (b) threatened fish availability according to IUCN status (Bangladesh, 2015), and (c) IUCN status (Global, 2015).

According to Islam et al. [10], there were 23 families in the Payra River, which is extremely comparable to our current study. Perciformes was the most prominent family, while Cypriniformes contributed a significant share of the species abundance, according to the order-based composition.

Table 3. List of fish species found in Payra river (Pandov point) and their contribution with IUCN status IUCN Bangladesh [29].

\begin{tabular}{|c|c|c|c|c|c|c|c|}
\hline Order & Family & $\begin{array}{l}\text { Local } \\
\text { Name }\end{array}$ & $\begin{array}{l}\text { Common } \\
\text { Name }\end{array}$ & Scientific Name & $\begin{array}{l}\text { IU } \\
\text { CN } \\
\text { (B } \\
\text { D) }\end{array}$ & $\begin{array}{c}\text { IUC } \\
\mathrm{N} \\
\text { (Glo } \\
\text { bal) }\end{array}$ & $\begin{array}{c}\% \\
\text { Contribut } \\
\text { ion }\end{array}$ \\
\hline \multirow{3}{*}{ Cypriniformes } & Cyprinidae & Catla & Catla & $\begin{array}{l}\text { Gibelion catla } \\
\text { (Hamilton,1822) }\end{array}$ & LC & NE & 0.1 \\
\hline & Cyprinidae & Mrigal & Mrigal carp & $\begin{array}{l}\text { Cirrhinus cirrhosus } \\
\text { (Bloch, 1795) }\end{array}$ & NT & VU & 0.14 \\
\hline & Cyprinidae & Rui & Roho labeo & $\begin{array}{l}\text { Labeo rohita } \\
\text { (Hamilton,1822) }\end{array}$ & LC & LC & 0.09 \\
\hline
\end{tabular}




\begin{tabular}{|c|c|c|c|c|c|c|c|}
\hline & Cyprinidae & Kalibaus & Black rohu & $\begin{array}{l}\text { Labeo calbasu } \\
\text { (Hamilton,1822) }\end{array}$ & LC & $\mathrm{LC}$ & 0.08 \\
\hline & Cyprinidae & Bata & Bata labeo & $\begin{array}{l}\text { Labeo bata } \\
\text { (Hamilton,1822) }\end{array}$ & LC & $\mathrm{LC}$ & 0.12 \\
\hline & Cyprinidae & Chebli & Giant danio & $\begin{array}{l}\text { D. aequipinnatus } \\
\text { (MacClelland,1839) }\end{array}$ & $\mathrm{DD}$ & $\mathrm{LC}$ & 1.09 \\
\hline & Cyprinidae & Darkina & $\begin{array}{l}\text { Gangetic } \\
\text { scissortail } \\
\text { rasbora }\end{array}$ & $\begin{array}{l}\text { Rasbora rasbora } \\
\text { (Hamilton,1822) }\end{array}$ & NT & $\mathrm{LC}$ & 2.8 \\
\hline & Cyprinidae & Dhela & Cotio & $\begin{array}{l}\text { Osteobrama cotio } \\
\text { (Hamilton,1822) }\end{array}$ & NT & $\mathrm{LC}$ & 1.38 \\
\hline & Cyprinidae & Mola & Indian carplet & $\begin{array}{l}\text { A. microlepis } \\
\text { (De Filippi,1863) }\end{array}$ & LC & NE & 1.76 \\
\hline & Cyprinidae & $\begin{array}{l}\text { Chep } \\
\text { chela }\end{array}$ & $\begin{array}{l}\text { Silver hatchet } \\
\text { barb }\end{array}$ & $\begin{array}{l}\text { Chela cachius } \\
\text { (Hamilton,1822) }\end{array}$ & VU & $\mathrm{LC}$ & 1.36 \\
\hline & Cyprinidae & Mola & Mola carplet & $\begin{array}{l}\text { A. mola } \\
\text { (Hamilton,1822) }\end{array}$ & LC & $\mathrm{LC}$ & 1.81 \\
\hline & Cyprinidae & Punti & Puntio barb & $\begin{array}{l}\text { Puntius puntio } \\
\text { (Hamilton,1822) }\end{array}$ & $\mathrm{DD}$ & NE & 1.04 \\
\hline & Cyprinidae & $\begin{array}{l}\text { Bhadi } \\
\text { punti }\end{array}$ & Pool barb & $\begin{array}{l}\text { Puntius sophore } \\
\text { (Hamilton,1822) }\end{array}$ & LC & $\mathrm{LC}$ & 5.26 \\
\hline & Cyprinidae & Tit punti & Ticto barb & $\begin{array}{l}\text { Pethia ticto } \\
\text { (Hamilton,1822) }\end{array}$ & VU & $\mathrm{LC}$ & 1.3 \\
\hline & Cyprinidae & Chela & $\begin{array}{l}\text { Large } \\
\text { razorbelly } \\
\text { minnow }\end{array}$ & $\begin{array}{l}\text { Salmophasia bacaila } \\
\text { (Hamilton,1822) }\end{array}$ & LC & $\mathrm{LC}$ & 2.32 \\
\hline & Cobitidae & Gutum & Guntea loach & $\begin{array}{l}\text { L. guntea } \\
\text { (Hamilton,1822) }\end{array}$ & LC & $\mathrm{LC}$ & 0.8 \\
\hline \multirow{7}{*}{ Perciformes } & Channidae & Cheng & $\begin{array}{l}\text { Dwarf } \\
\text { snakehead }\end{array}$ & $\begin{array}{l}\text { Channa gachua } \\
\text { (Hamilton,1822) }\end{array}$ & LC & $\mathrm{LC}$ & 0.54 \\
\hline & Channidae & Gozar & $\begin{array}{l}\text { Great } \\
\text { snakehead }\end{array}$ & $\begin{array}{l}\text { Channa marulius } \\
\text { (Hamilton,1822) }\end{array}$ & EN & $\mathrm{LC}$ & 0.06 \\
\hline & Channidae & Ranga & $\begin{array}{l}\text { Walking } \\
\text { snakehead }\end{array}$ & $\begin{array}{l}\text { Channa orientalis } \\
\text { (Block \& Schneider, } \\
\text { 1801) }\end{array}$ & LC & $\mathrm{LC}$ & 0.47 \\
\hline & Channidae & Taki & $\begin{array}{l}\text { Spotted } \\
\text { snakehead }\end{array}$ & $\begin{array}{l}\text { Channa punctata } \\
\text { (Bloch,1793) }\end{array}$ & LC & $\mathrm{LC}$ & 0.45 \\
\hline & Channidae & Shol & $\begin{array}{l}\text { Striped } \\
\text { snakehead }\end{array}$ & $\begin{array}{l}\text { Channa striata } \\
\text { (Bloch,1793) }\end{array}$ & LC & $\mathrm{LC}$ & 0.3 \\
\hline & $\begin{array}{l}\text { Anabantida } \\
\text { e }\end{array}$ & Koi & Climbing perch & $\begin{array}{l}\text { Anabas testudineus } \\
\text { (Bloch,1792) }\end{array}$ & LC & DD & 0.54 \\
\hline & Ambassida & Nalua & Scalloped & Ambassis nalua & $\mathrm{DD}$ & $\mathrm{LC}$ & 1.8 \\
\hline
\end{tabular}




\begin{tabular}{|c|c|c|c|c|c|c|c|}
\hline & e & chanda & perchlet & (Hamilton,1822) & & & \\
\hline & $\begin{array}{l}\text { Ambassida } \\
\text { e }\end{array}$ & $\begin{array}{l}\text { Ranga } \\
\text { chanda }\end{array}$ & $\begin{array}{l}\text { Indian glassy } \\
\text { fish }\end{array}$ & $\begin{array}{l}\text { Parambassis ranga } \\
\text { (Hamilton,1822) }\end{array}$ & LC & $\mathrm{NE}$ & 1.4 \\
\hline & Gobiidae & Bele & Tank goby & $\begin{array}{l}\text { Glossogobius giuris } \\
\text { (Hamilton,1822) }\end{array}$ & LC & LC & 1.21 \\
\hline & Gobiidae & Bailla & $\begin{array}{l}\text { Pacific river } \\
\text { goby }\end{array}$ & $\begin{array}{l}\text { Awaous guamensis } \\
\text { (Valenciennes, 1837) }\end{array}$ & LC & LC & 0.65 \\
\hline & Gobiidae & Chewa & $\begin{array}{l}\text { Pointed-tailed } \\
\text { goby }\end{array}$ & $\begin{array}{l}\text { Psedapocryptes elongates } \\
\text { (Cuvier, 1837) }\end{array}$ & $\mathrm{LC}$ & LC & 1.56 \\
\hline & Gobiidae & Dogri & $\begin{array}{l}\text { Burrowing } \\
\text { goby }\end{array}$ & $\begin{array}{l}\text { Trypauchen vagina (Bloch } \\
\text { \& J.G. Schneider, 1801) }\end{array}$ & $\mathrm{LC}$ & NE & 1.35 \\
\hline & Gobiidae & $\begin{array}{l}\text { Dali } \\
\text { chewa }\end{array}$ & Mudskipper & $\begin{array}{l}\text { Apocryptes bato } \\
\text { (Hamilton,1822) }\end{array}$ & $\mathrm{LC}$ & LC & 1.53 \\
\hline & Gobiidae & Dahuk & Walking goby & $\begin{array}{l}\text { S. histophorus } \\
\text { (Valenciennes, 1837) }\end{array}$ & LC & $\mathrm{NE}$ & 1.89 \\
\hline & $\begin{array}{l}\text { Osphronem } \\
\text { idae }\end{array}$ & $\begin{array}{l}\text { Lal } \\
\text { kholisha }\end{array}$ & Dwarf gourami & $\begin{array}{l}\text { Trichogaster lalius } \\
\text { (Hamilton,1822) }\end{array}$ & LC & $\mathrm{LC}$ & 2.07 \\
\hline & Sciaenidae & Poa & Pama croaker & $\begin{array}{l}\text { Otolithoides pama } \\
\text { (Hamilton,1822) }\end{array}$ & LC & $\mathrm{NE}$ & 0.3 \\
\hline & Sillaginidae & $\begin{array}{l}\text { Tular } \\
\text { dandi }\end{array}$ & Flathead sillago & $\begin{array}{l}\text { Sillaginopsis panijus } \\
\text { (Hamilton,1822) }\end{array}$ & LC & $\mathrm{NE}$ & 0.31 \\
\hline & $\begin{array}{l}\text { Polynemida } \\
\text { e }\end{array}$ & Taposi & $\begin{array}{l}\text { Paradise } \\
\text { threadfin }\end{array}$ & $\begin{array}{l}\text { P. paradiseus } \\
\text { (Linnaeus, 1758) }\end{array}$ & LC & $\mathrm{NE}$ & 0.8 \\
\hline \multirow{7}{*}{ Siluriformes } & Bagridae & $\begin{array}{l}\text { Gulsha } \\
\text { Tengra }\end{array}$ & $\begin{array}{l}\text { Bleeker's } \\
\text { mystus }\end{array}$ & $\begin{array}{l}\text { Mystus bleekeri } \\
\text { (Hamilton,1822) }\end{array}$ & LC & LC & 1.7 \\
\hline & Bagridae & Tengra & $\begin{array}{l}\text { Striped drawf } \\
\text { catfish }\end{array}$ & $\begin{array}{l}\text { Mystus vittatus } \\
\text { (Bloch,1794) }\end{array}$ & $\mathrm{LC}$ & LC & 2.01 \\
\hline & Bagridae & $\begin{array}{l}\text { Nuna } \\
\text { tengra }\end{array}$ & $\begin{array}{l}\text { Long whiskers } \\
\text { catfish }\end{array}$ & $\begin{array}{l}\text { Mystus gulio } \\
\text { (Hamilton,1822) }\end{array}$ & NT & LC & 0.84 \\
\hline & Pangasiidae & Pangas & $\begin{array}{l}\text { Yellowtail } \\
\text { Catfish }\end{array}$ & $\begin{array}{l}\text { Pangasius pangasius } \\
\text { (Hamilton,1822) }\end{array}$ & EN & LC & 0.08 \\
\hline & Schilbeidae & Batasi & Indian potasi & $\begin{array}{l}\text { P. atherinoides } \\
\text { (Bloch,1794) }\end{array}$ & LC & LC & 2.04 \\
\hline & Schilbeidae & Shilong & Silond catfish & $\begin{array}{l}\text { Silonia silondia } \\
\text { (Hamilton,1822) }\end{array}$ & LC & LC & 0.15 \\
\hline & Schilbeidae & Ghaura & Garua bacha & $\begin{array}{l}\text { Clupisoma garua } \\
\text { (Hamilton,1822) }\end{array}$ & EN & $\mathrm{NE}$ & 1.31 \\
\hline \multirow{3}{*}{ Clupeiformes } & $\begin{array}{l}\text { Engraulida } \\
\text { e }\end{array}$ & Phasa & $\begin{array}{l}\text { Gangetic } \\
\text { hairfin anchovy }\end{array}$ & $\begin{array}{l}\text { Setipinna phasa } \\
\text { (Hamilton, 1822) }\end{array}$ & LC & LC & 1.17 \\
\hline & Clupeidae & Chapila & $\begin{array}{l}\text { Indian river } \\
\text { shad }\end{array}$ & $\begin{array}{l}\text { Gudusia chapra } \\
\text { (Hamilon, 1822) }\end{array}$ & VU & LC & 1 \\
\hline & Clupeidae & Kachki & Ganges river & Corica soborna & LC & LC & 19.44 \\
\hline
\end{tabular}




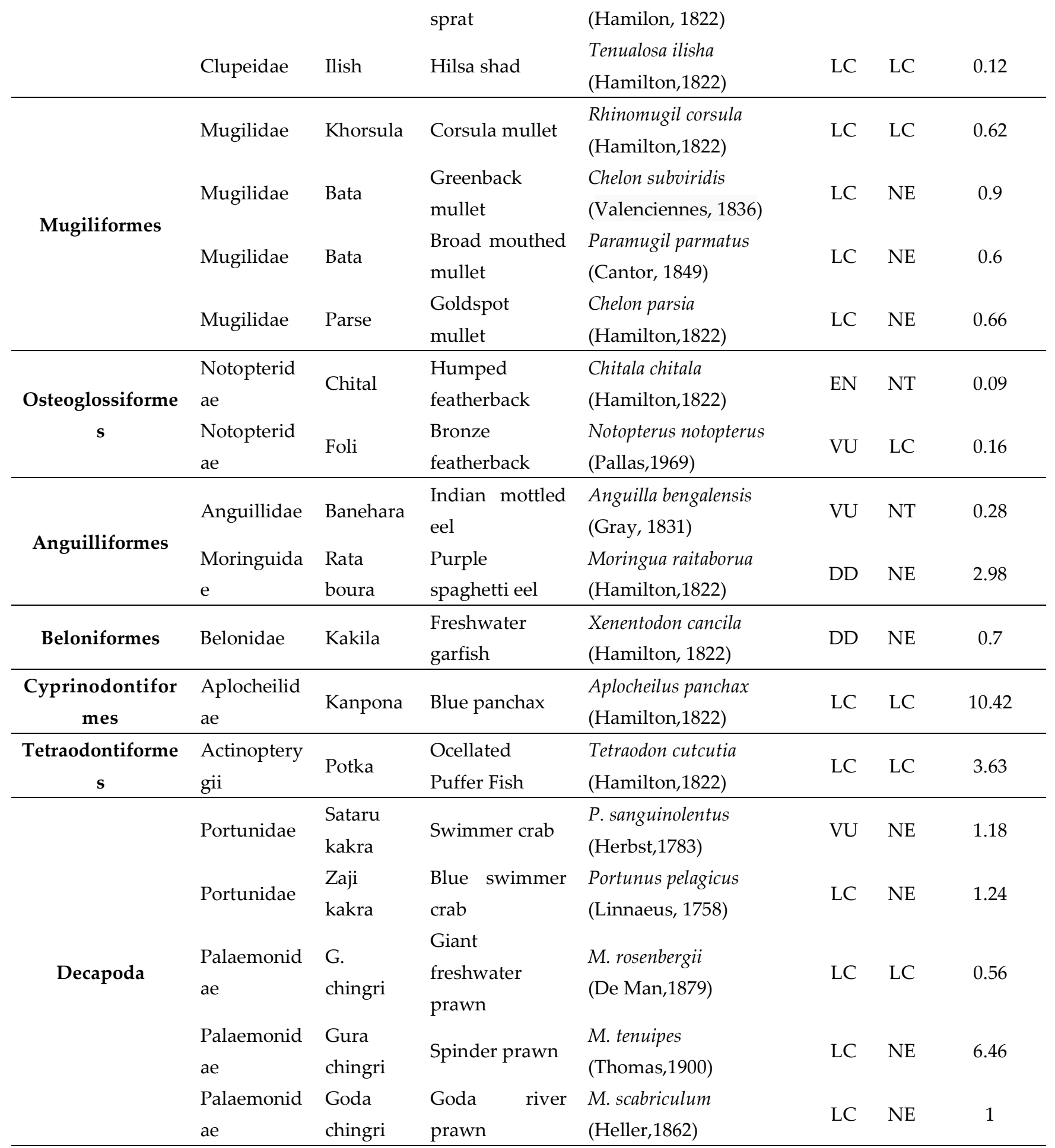

N.B. EN: endangered, VU: vulnerable, NT: near threatened, LC: least concern and DD: data deficient, NE: not evaluated, R. (Ranga) Chanda; N. (Nalua) Chanda; G. (Golda) chingri; G. (Gulsha) Tengra.

\subsection{Biodiversity Indices}

3.3.1. Shannon-Weaver Diversity Index $\left(\mathrm{H}^{\prime}\right)$ 
The Shannon-Weaver's diversity value was highest in monsoon $(3.46 \pm 0.03)$ and lowest in winter $(3.22 \pm 0.04)$ with a mean value of $3.33 \pm 0.12$ (Figure $5 a)$. This indicates that the study area was most diversified in monsoon and less diversified in the winter. There was significant seasonal variation $(p<0.05)$ for the Shannon-Weaver diversity index $\left(\mathrm{H}^{\prime}\right)$ in the study area. The Payra river's diversity index value oscillated from 3.22 to 3.46, indicating slight pollution (Table 4).

Table 4. Shannon-Weaver diversity index and pollution level.

\begin{tabular}{ccccc}
\hline Value Range $\left(\mathbf{H}^{\prime}\right)$ & $0-1$ & $1-2$ & $2-3$ & $3-4$ \\
\hline Interpretation & Heavy & Moderate & Light & Slight \\
\hline Present findings (average) & \multicolumn{4}{c}{$3.33 \pm 0.12$} \\
\hline
\end{tabular}

\subsubsection{Margalef Richness Index (d)}

The Margalef richness index (d) value was maximum in monsoon $(7.76 \pm 0.27)$ and minimum in winter $(7.19 \pm 0.38$ ) with an average value of $7.60 \pm 0.32$ (Figure $5 b$ ). Throughout the year-round study period, we can see that from the values the rainy season was the most species-rich season and winter was the least species-rich season. In addition, there was a significant variation in the richness index (d) between seasons $(p<0.05)$. The richness index was used to calculate the pollution level at the sampling places and estimated as a clear water environment in the data collecting stations and their immediate surroundings (Table 5).

Table 5. Margalef's Richness Index (d) and pollution level [19].

\begin{tabular}{cccccc}
\hline Value Range (d) & $0-1$ & $1-2$ & $2-4$ & $4-6$ & $>6$ \\
\hline Interpretation & $\begin{array}{c}\text { More Serious } \\
\text { Pollution }\end{array}$ & $\begin{array}{c}\text { Serious } \\
\text { pollution }\end{array}$ & $\begin{array}{c}\text { Moderate } \\
\text { Pollution }\end{array}$ & $\begin{array}{c}\text { Light } \\
\text { Pollution }\end{array}$ & $\begin{array}{c}\text { Clear } \\
\text { Water }\end{array}$ \\
\hline $\begin{array}{c}\text { Present findings } \\
\text { (average) }\end{array}$ & & & $7.60 \pm 0.32$ & & \\
\hline
\end{tabular}

\subsubsection{Pielou's Evenness Index (J')}

The Pielou's evenness index $\left(\mathrm{J}^{\prime}\right)$ value shows that all the species were more or less evenly distributed all year round but most evenly distributed in monsoon $(0.54 \pm 0.01)$ and relatively less in summer $(0.44 \pm 0.05)$ with an average value of $0.48 \pm 0.05$ (Figure $5 \mathrm{c}$ ). In the case of the evenness index, there was observed fluctuation across seasons $(p<0.05)$. 

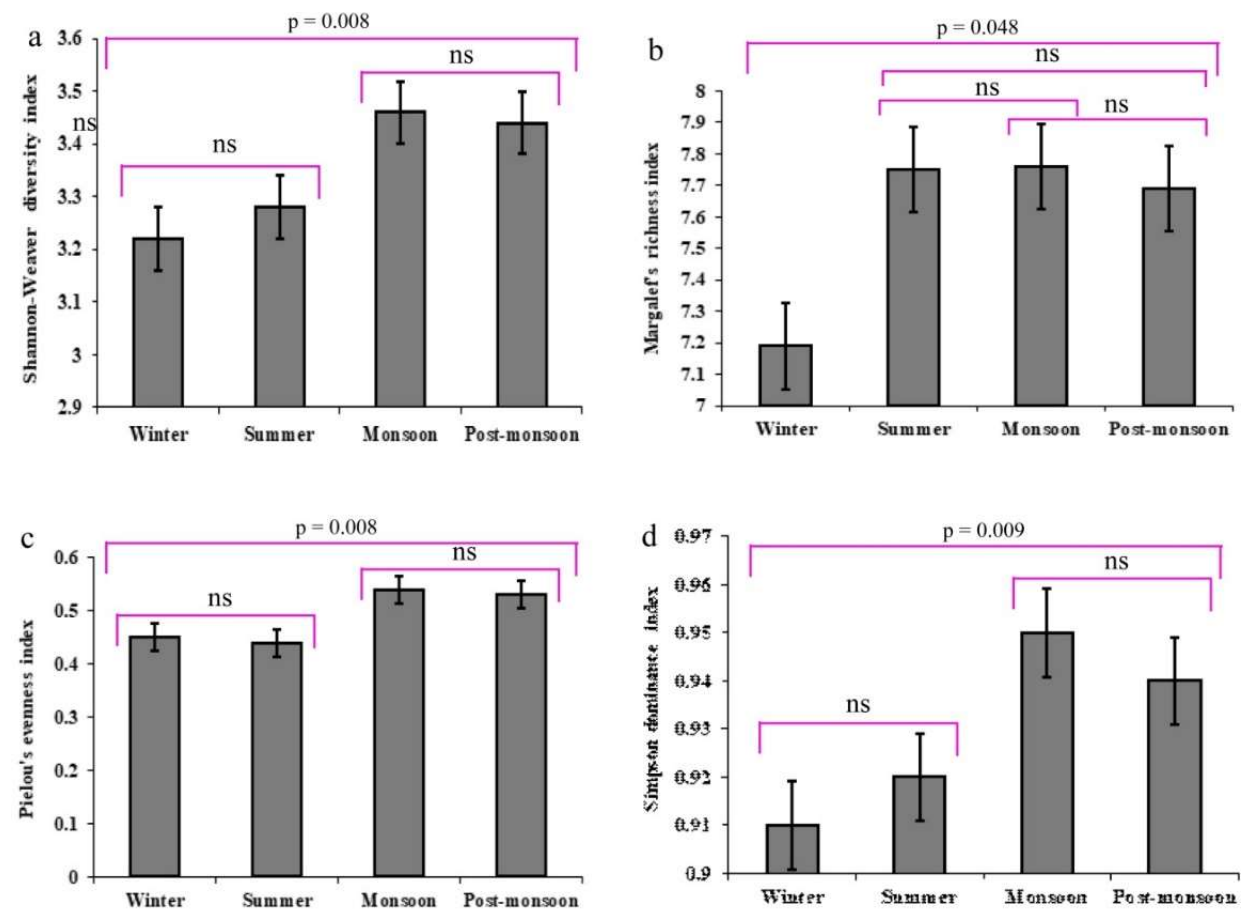

Figure 5. Different diversity indices value measured in the Payra river, a) Shannon-Weaver diversity index $\left(\mathrm{H}^{\prime}\right)$; b) Margalef richness index (d); Pielou's evenness index $\left(J^{\prime}\right)$; and (d) Simpson dominance index (c). Values are differed significantly at $(p<0.05)$ among seasons. 'ns' indicates no significant difference.

\subsubsection{Simpson dominance index (c)}

The Simpson's dominance index (c) value ranged from $0.95 \pm 0.00$ in monsoon and $0.91 \pm 0.00$ in winter with an average value of $0.93 \pm 0.02$ (Figure $5 \mathrm{~d}$ ). This implies that some species were dominant over others during the winter, but that most species were less dominant during the monsoon.

The goal of a biodiversity index is to use a single number to describe the diversity of a sample or population [33]. The concept of "species diversity" has two parts: the number of species or richness, and the distribution of individuals within species. The ShannonWeaver diversity index takes into account species diversity, whereas the Evenness and Dominance indices measure the sample's relative number of individuals and the fraction of common species, respectively. The richness and proportion of each species are represented by the Margalef richness index. During the study period, the Shannon-Weaver's diversity value was highest in monsoon (3.46 \pm 0.03$)$ and lowest in winter $(3.22 \pm 0.04)$ with a mean value of $3.33 \pm 0.12$. This indicates that the study area was most diversified in monsoon and less diversified in the winter. In the Meghna river estuary, Hossain et al. [4] found 3.19, while Nair et al. [34] found the same results. For ecological data, the Shannon-Weaver diversity index $\left(\mathrm{H}^{\prime}\right)$ value normally varies from 1.5 to 3.5 , with a maximum of 5.0 when the samples contain 1,000 species [35]. Nabi et al. [36] reported the Shannon-Weaver value as 0.95-2.62 in the Bakkhali river, In the Kushiyara river, Shannon-Weaver diversity values range from 2.35-2.65, according to Rahman et al. [37]. In each scenario, a low Shannon diversity index is associated with a small number of individuals, while a high Shannon diversity index is associated with a large number of individuals. Seasonal fluctuations in nutrients in seagrass beds, which affect the cohabitation of many fish species [38], atmospheric air currents and ambient conditions [39], and 
seasonal fish migrations, are the main drivers of differences in biodiversity indexes [40]. There was a discernible difference in Shannon $\left(\mathrm{H}^{\prime}\right)$ diversity. As a result, it is possible to conclude that seasonal differences in species diversity are a typical occurrence in the examined area, indicating a well-distributed fish population in the Payra river. The Margalef richness index (d) value was maximum in monsoon $(7.76 \pm 0.27)$ and minimum in winter $(7.19 \pm 0.38)$ with an average value of $7.60 \pm 0.32$. The Margalef richness value, which is employed as a comparison indicator, generally exhibits variation depending on the number of species [12]. The highest species number, (2234) shows the maximum Margalef richness value (7.91) where the minimum value was observed at (6.60) with the lowest number of species (67) [41]. Vyas et al. [12] reported the Margalef index in the Betwa River in Madhya Pradesh of India ranging from 3.71 to 6.70. Throughout the year-round study period, we can see that from the values the rainy season was the most species-rich season and winter was the least species-rich season and indicating that the Payra river is usually species-rich.

The Pielou's evenness index $\left(J^{\prime}\right)$ value shows that all the species were more or less evenly distributed all year round but most evenly distributed in monsoon $(0.54 \pm 0.01)$ and relatively less in summer $(0.44 \pm 0.05)$ with an average value of $0.48 \pm 0.05$ in the Payra river. In the case of the evenness index, there was observed fluctuation across seasons $(p<0.05)$. The highest and lowest evenness value was recorded in Halda river was 0.61 and 0.50 respectively [41]. This means all the species was more or less evenly distributed all year round in the Payra river. The Simpson's dominance index (c) value ranged from $0.95 \pm 0.00$ in monsoon and $0.91 \pm 0.00$ in winter with an average value of $0.93 \pm 0.02$. This implies that some species were dominant over others during the winter, but that most species were less dominant during the monsoon in our present study in the Payra river. For the Halda river, the greatest Simpson dominance index value was 0.95, while the lowest value was 0.94, indicating that the dominance was shared by more species for the highest value [41] which is fairly in agreement with the present findings. All the findings indicated that the Payra river is a moderately species-rich water body where most of the species were evenly distributed. In the present study, the health condition of the Payra river was found satisfactory according to the pollution level of Staub [20] based on the Shannon-weaver diversity indices value. The pollution level was also assessed by Lad [19] based on Margalef's Richness index and found clear water. We also found four near-threatened species, six vulnerable species, and four endangered species [29] which may need proper management of this water body to conserve the threatened fishes.

\subsection{Cluster Analysis}

Based on the species encountered, a cluster analysis of the acquired species from the sampling places was performed. According to the Bray-Curtis similarity matrix, the research revealed that the species were $80 \%$ similar and were grouped into three clusters. The first cluster, which contains 46 species, was the largest in the Payra river. The second and third clusters, respectively, contain 11 and 4 species. The cluster analysis found a $25 \%$ separation for species at the similarity level (Figure 6). First cluster separation starts with S. silondia at the similarity level of $25 \%$ among all species. Seasonality, which is responsible for fluctuating hydrological and meteorological conditions that change the fish assemblage in estuaries, has a major impact on the similarity and dissimilarity of species occurrence [42-44]. Seasonality has an impact on fish spawning activity, which in turn has an impact on capture composition [45]. In the Payra river, we identified $80 \%$ similarity among the species and divided them into three distinct clusters at a $25 \%$ similarity level. Hossain et al. [4] discovered more commonalities across months than between various sites, and he revealed two distinct clusters in the Meghna estuary. The presence, distribution, abundance, and diversity of riverine tropical fishes are influenced by several interconnected physical and biological processes. Water salinity, temperature, turbidity, 
and dissolved oxygen, as well as their regular or irregular variations at various time intervals, have been found as determinants in estuarine fish ecology $[42,46]$.

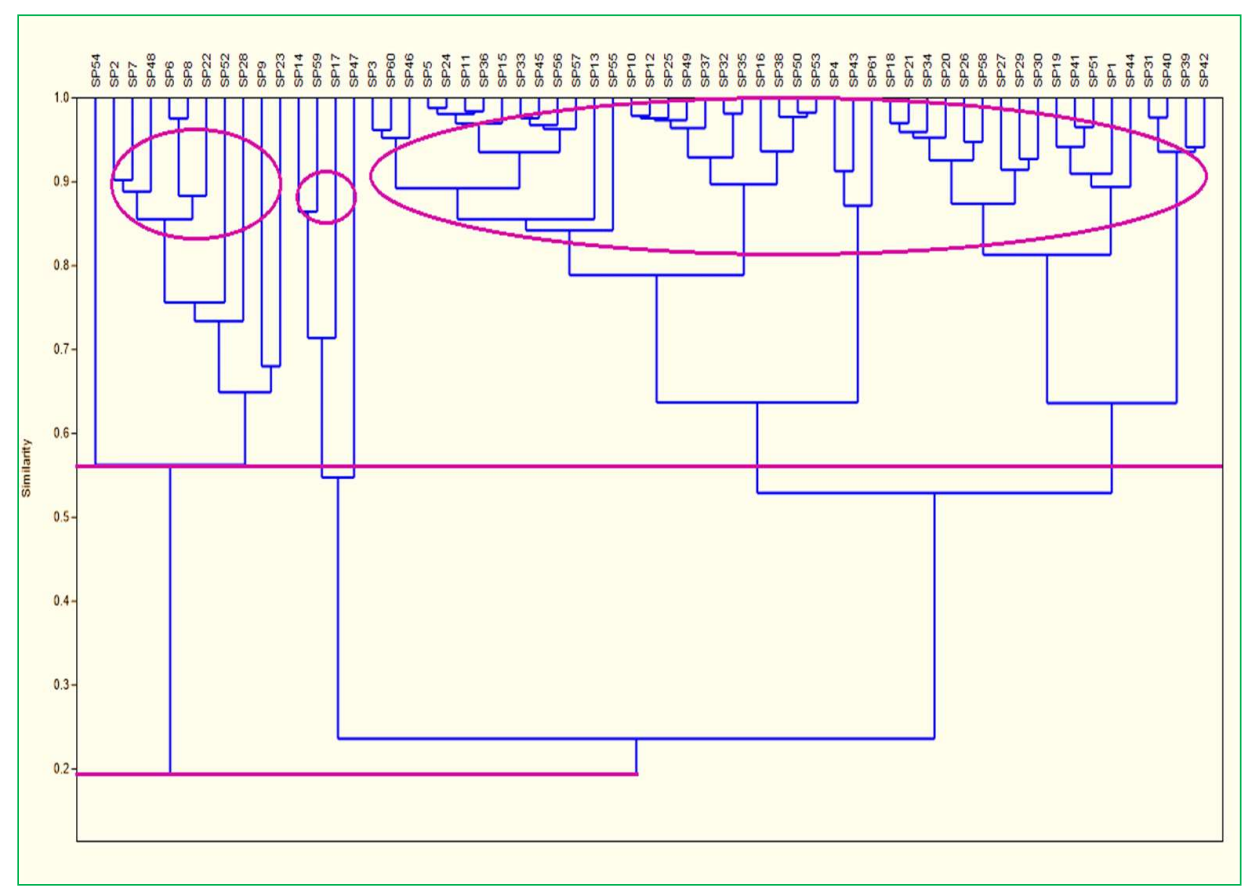

Figure 6. The temporal cluster of fish composition is based on Bray-Curtis similarity matrix.

\subsection{Canonical Correspondence Analysis (CCA)}

For the first three-axis (CCA1, CCA2, and CCA3), Eigenvalues of CCA (meteorological parameters) were found to be $0.026616,0.0059284$, and 0.00045777 , respectively (Table 6). The cumulative percentage variance of species for the first three axes was $99.997 \%$. The first and second axes, respectively, represented $80.65 \%$ and $17.96 \%$ of the species data, and the findings from the first two axes were plotted in Figure 7.

Table 6. Eigenvalues, percentage of variance, and percentage of cumulative variance for the first three factors of finfish and shellfish samples were collected from the Payra river of Bangladesh.

\begin{tabular}{ccccc}
\hline Axes & Eigenvalue & \% of Variance & Cumulative \% & $\boldsymbol{p}$-value \\
\hline CCA1 & 0.026616 & 80.65 & 80.65 & 0.749 \\
CCA2 & 0.0059284 & 17.96 & 98.61 & 0.08 \\
CCA3 & 0.00045777 & 1.387 & 99.997 & 0.873 \\
\hline
\end{tabular}

The CCA biplot of ten main fish species highlighted their reliance on environmental conditions. 


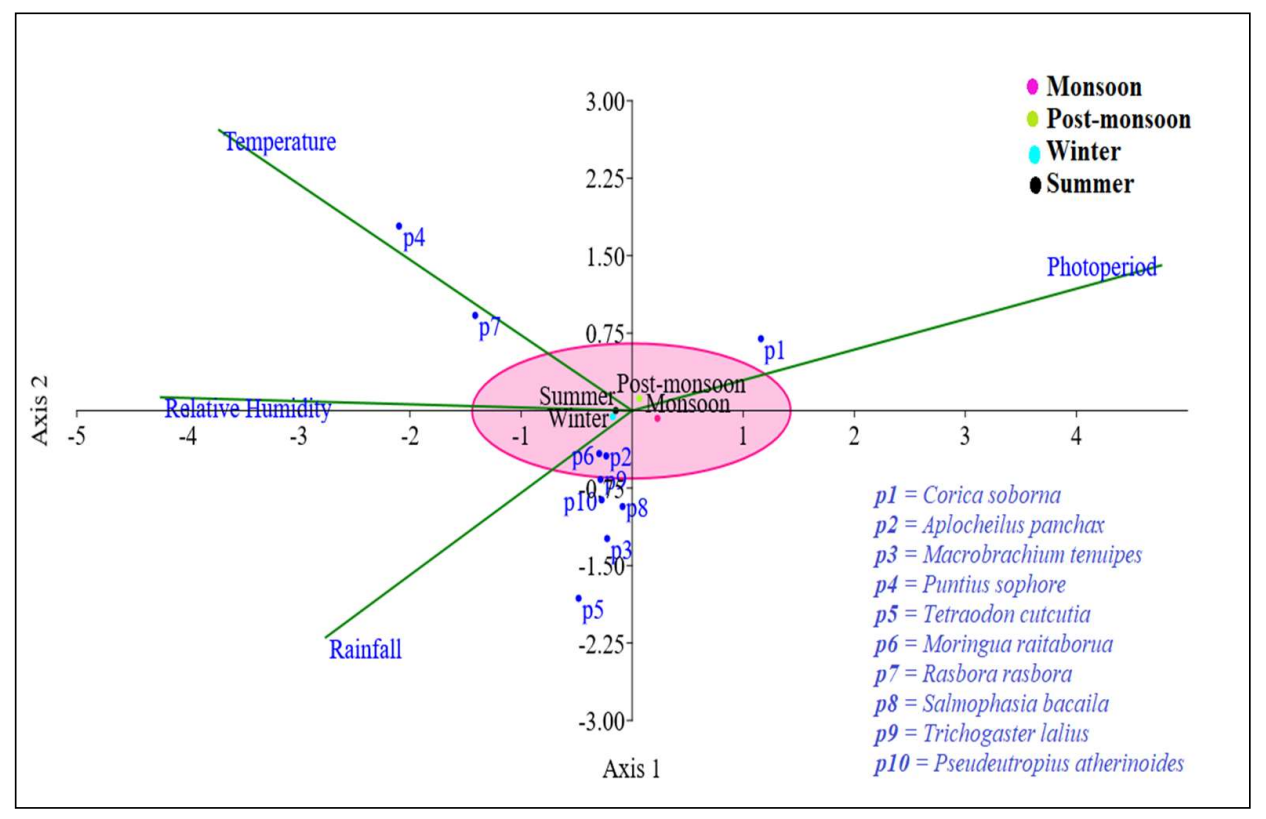

Figure 7. The CCA illustrates the link between climatic variables and the dominant fish species in the study area.

Only rainfall, out of the four meteorological characteristics or variables, was found to have a major impact on fish dispersion in the Payra River during different seasons (Figure 7). During the monsoon and post-monsoon seasons, the photoperiod had a significant impact on the Corica soborna (p1). Puntius sophore (p4) and Rasbora rasbora (p7) is the species most impacted by temperature. Except for p1, p4, and p7, rainfall was the most influential climatic condition for the distribution of all species outside of the winter season. The CCA plot clearly shows that rainfall and temperature were the key determinants of species distribution in the Payra river during the current study. Effects of environmental variables on species distributions were tested by CCA analysis. CCA analysis showed that among meteorological parameters rainfall and temperature was the major driver that impacts on species distribution in Payra river. Fish communities are highly affected by temperature within estuaries [47]. A sudden increase or decrease in water temperature may cause fish mortality [46]. $\mathrm{pH}$ is the most important hydrological factor for species distribution though Nabi et al. [36] found very little impact of this parameter on fish distribution at the Bakkhali river estuary. The two most important climatic characteristics determining species assemblage structure in the Kushiyara River, according to Rahman et al. [37] are air temperature and rainfall which is in conformation with the present study.

\subsection{Phytoplankton Community Structure, Diversity Index, and Pollution Level}

During the study period, the phytoplankton population in the Payra river basin was represented by 32 species split into five phytoplanktonic groups (Table 7).

Table 7. Monthly average abundance (Ind./L) of phytoplanktonic species in the Payra river.

\begin{tabular}{|c|c|c|c|}
\hline Plankton & Family & Species & Average $\left(1 \times 10^{3}\right.$ cells $\left.L^{-1}\right)$ \\
\hline \multirow{2}{*}{ 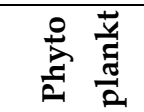 } & \multirow{2}{*}{ Bacillariophyceae } & Asterionella glacials & 1 \\
\hline & & Bacillaria paxillifer & 1 \\
\hline
\end{tabular}




\begin{tabular}{|c|c|c|}
\hline & \multirow{4}{*}{$\begin{array}{l}\text { Cyclotella operculata } \\
\text { Amphora ovalis } \\
\text { Eraoellaria construens }\end{array}$} & \multirow[b]{2}{*}{2} \\
\hline & & \\
\hline & & 1 \\
\hline & & 5 \\
\hline & Navicula distans & 44 \\
\hline & Polycystis naegeli & 1 \\
\hline & Surirella gemma & 11 \\
\hline \multirow{13}{*}{ Chlorophyceae } & Tabellaria fenestrata & 1 \\
\hline & Ceratium belone & 1 \\
\hline & Chlorella vulgaris & 21 \\
\hline & Closterium microporum & 3 \\
\hline & Eudorina elegans & 1 \\
\hline & Gonatozyon monotaenium & 1 \\
\hline & Nannochloris bacillaris & 22 \\
\hline & Oedogonium minus & 1 \\
\hline & Pediastrum duplex & 2 \\
\hline & Pleurococcus vulgaris & 4 \\
\hline & Scenedesmus acutes & 1 \\
\hline & Spirogyra singularis & 10 \\
\hline & Volvox barberi & 1 \\
\hline \multirow{6}{*}{ Cyanophyceae } & Zygnema cylindricum & 1 \\
\hline & Anabaena flos-aquae & 4 \\
\hline & Gloeocapsa atrata & 1 \\
\hline & Gomphosphaeria wichurae & 2 \\
\hline & Oscillatoria amphibia & 1 \\
\hline & Spirulina major & 1 \\
\hline \multirow{4}{*}{ Dinophyceae } & Stephanodiscus niagarae & 1 \\
\hline & Dinobryon sertularia & 1 \\
\hline & Dinophysis mitra & 1 \\
\hline & Ulothrix aequalies & 14 \\
\hline Euglenaceae & Euglena acus & 14 \\
\hline \multicolumn{2}{|c|}{ Total species } & 32 \\
\hline
\end{tabular}

Thirteen species belonged to the Chlorophyceae family, eight to the Bacillariophyceae family, six to the Cyanophyceae family, four to the Dinophyceae family, and one to the Euglenaceae family (Table 7). The Shannon-weaver diversity index, Margalef richness index, Pielou's Evenness index, and Simpson dominance index had mean annual values of $11.49 \pm 0.19,1.99 \pm 0.66,0.45 \pm 0.07$, and $0.66 \pm 0.20$, respectively. Based on the Palmer [14] score, the Shannon-weaver diversity index value indicated moderate to severe pollution in the research area. Palmer's pollution index value, based on the algal tolerant group and algal tolerant species, suggested a lack of organic pollution to probable high organic pollution during the investigation in the Payra river. Our findings differ significantly from those of Pramila et al. [48] at Ambazari Lake. 
On the planet, wetlands are maybe losing quicker than some other sorts of territories. In truth, the siltation of water bodies contributes especially to aquatic habitat loss and degradation [49]. Rivers carry annually 2.4 billion MT silts, which are deposited on the river beds, floodplains, and beel bottoms [50]. During the study period, man-made activities were found as dominant decline causes of fish species in the Payra river. Even though the government has taken significant steps to conserve fish and has mandated a sustainable catch, however, indiscriminate overfishing continues during the fishing ban period (Figure 8). Overfishing is considered a key reason for the decline of fisheries [51]. Indiscriminate fishing by using different non-selective fishing gears was observed as a major threat to the decline of fish. In the Payra River, ten different types of fishing gear were identified, including five nets (Estuarine Set Bag Net, Beshal Jal, cotton net, Behundi Net, Kachki Jal), three hooks and lines (Long Line, Line, Hook), and two traps (Box Trap and Chai). Sultana et al. [52] reported 18 types of fishing gear to be used by the fishermen of which 5 gills, 1 seine, 2 fixed purses, 1 lift, 1 cast, 2 push/drag nets, 2 traps, 2 hooks, and lines and 2 wounding gears in Payra river. Saha et al. [53] reported 7 different types of gear of 3 categories (nets, traps, and wounding gears) used by 2 categorized fishers in the Gawha beel. The observed destruction level of behundi net was massive during the study period. Almost 200 to 250 individuals of 13 fish species were found in 100 grams of fishes caught by behundi net. The study suggests that cotton nets and behundi nets pose serious harm to the Payra river's fish species. In addition to inorganic pollution, pesticide and insecticide use such as hexaconazole and propiconazole used in pest management in riverside agriculture harm fish. Because hexaconazole causes oxidative stress in fish and altered mitochondrial bioenergetics could be a subsequent response to increased oxidative damage.

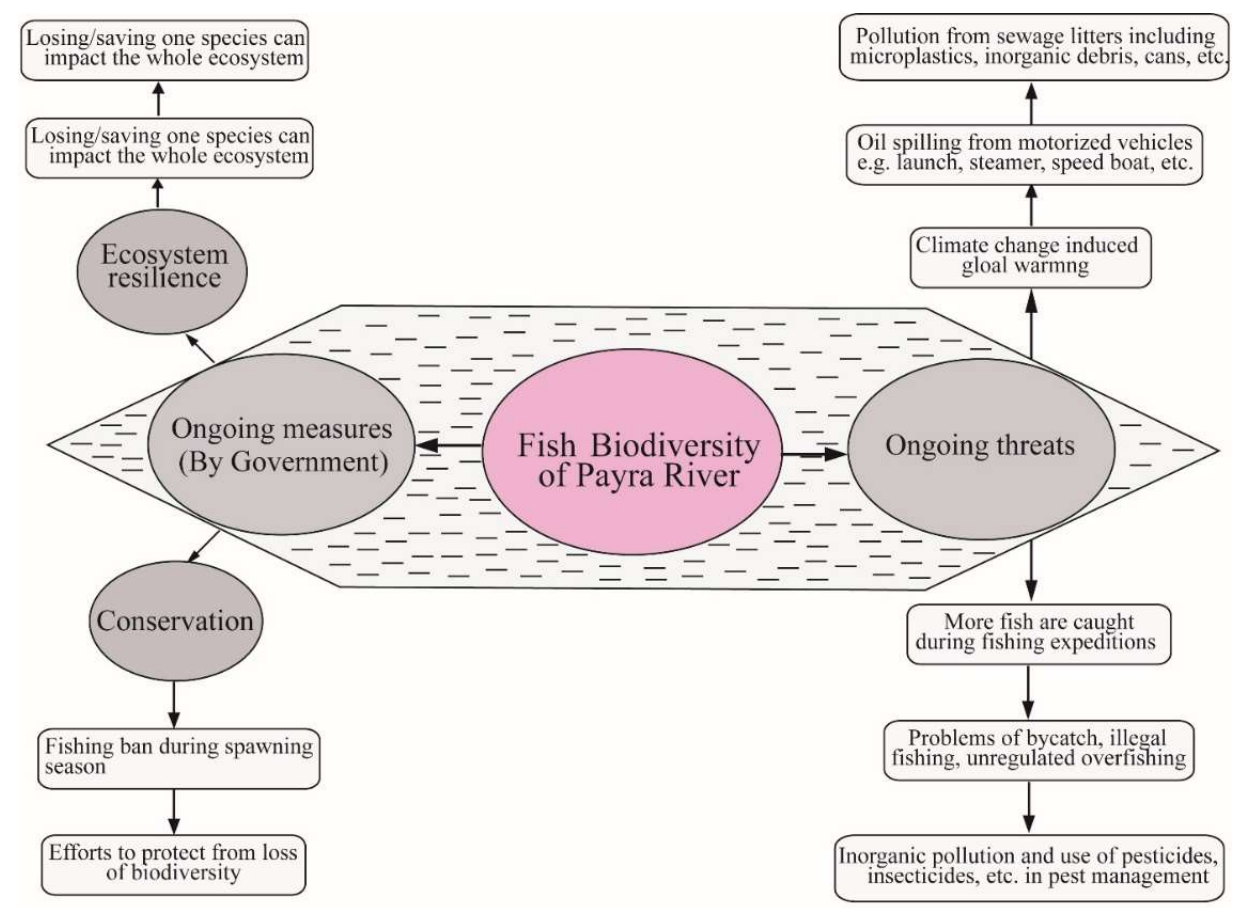

Figure 8. The current state of fish and shellfish biodiversity in the Payra River, as well as the government's ongoing threats mitigation measures.

On the other hand, propiconazole causes liver damage and the development of zebrafish embryos and larvae was dramatically slowed after exposure (Figure 9). It was also observed that several drains have fallen into the river from both banks. As a result, 
various chemical wastages from different sources fall through the drainage and polluted the water quality consequently destroying the spawning and nursing grounds of many commercially important fish species of the Payra river. Pesticides are mainly poisonous and thus are hazardous to aquatic organisms and affect ecosystem integrity and disrupt their functioning [54]. On the other hand, the construction of diversion canals and sluice gates causes heavy siltation in the river bed. Due to siltation, two big islands are developed in the river; one in the joining point of Karkhana river and Payra river and another in the middle portion of the river near Pangasia union. This siltation problem greatly influences the water flow consequently affecting the entire ecosystem of the river. Oil spilled mainly diesel from motorized vehicles (launch, steamer, speed boat) causes scum to build on the surface of the water, which prevents light from penetrating. The consolidated impacts of these dangers (siltation, habitat loss, conversion of wetland to agricultural fields, overfishing, dewatering during the lean season, poisoning, pesticides and fertilizers, climate change, etc.) might be harming the whole fisheries assets of this waterway.

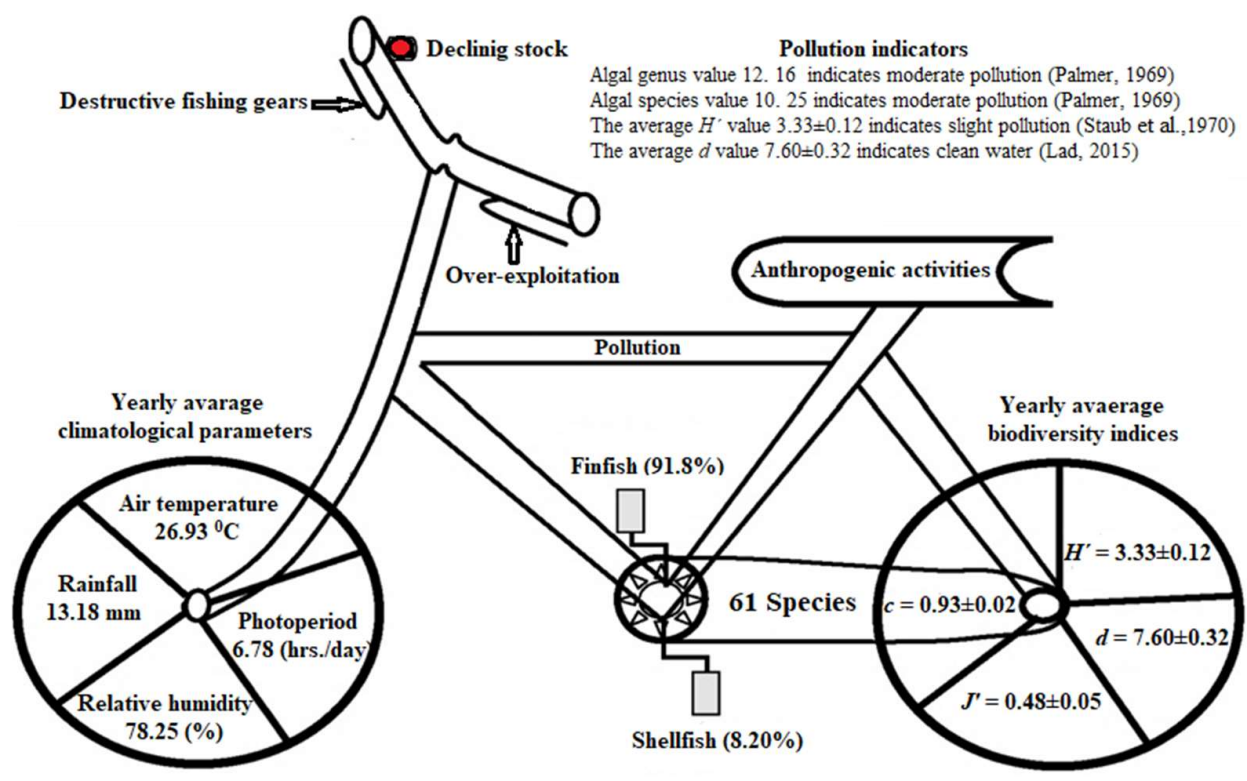

Figure 9. Driving forces of finfish and shellfish temporal distribution at Payra river Bangladesh.

\section{Conclusions}

This research was conducted for determining the temporal distribution of finfish and shellfish in the Payra River. Because of moderate pollution from chemical applications in agricultural land and high surface runoff containing pollution substances, as well as the presence of a brickfield alongside the river polluting both air and water, species diversity is lower than in prior comparable studies. Awareness making into the general fishermen through campaigning and training can result in sustainable fishing, avoiding catch of fish larvae, and can ensure controlled fishing during the breeding season. Finally, because fisheries are a renewable resource, they may be protected by implementing sound management strategies with the support of government agencies, non-governmental organizations, and other national and international organizations. The current study of finfish and shellfish distribution through time should be valuable for further ecological assessment and monitoring of the river's quality and its linked water bodies. 
Author Contributions: Conceptualization, N.R. and M.A.R.; methodology, M.A.R. and M.M.I.; software, M.A.R.R. and M.R.K.M; validation, M.A.R.; formal analysis, M.R.U. and S.C.; investigation, M.T.R. and K.R.H.; resources, M.A.R.; data curation, M.A.R.R.; writing-original draft preparation, M.A.R.R. and M.R.U.; writing-review and editing, M.A.R.; visualization, N.R. and M.A.R.; supervision, M.A.R; project administration, N.R. and M.A.R.; funding acquisition, N.R. and M.A.R. All authors have read and agreed to the published version of the manuscript.

Funding: “This research was funded by MINISTRY OF SCIENCE AND TECHNOLOGY (MoST) of Bangladesh under special allocation; grant number SL-66, BS-279" and "The APC was not included under this project".

Institutional Review Board Statement: Not applicable.

Informed Consent Statement: Not applicable.

Data Availability Statement: The data presented in this study are available on request from the corresponding author.

Acknowledgments: The authors are thankful to the fisher's community of the Payra River and adjacent waters for their co-operation in collecting the data. The authors are also grateful to the editor and anonymous reviewers of this journal for their constructive comments, corrections, and suggestions.

Conflicts of Interest: The authors declare no conflict of interest.

\section{References}

1. James, N.C.; Cowley, P.D.; Whitfield, A.K.; Lamberth, S.J. Fish communities in temporarily open/closed estuaries from the warm- and cool-temperate regions of South Africa: a review. Rev. Fish Biol. Fish. 2007, 17, 565-580. https://dx.doi.org/10.1007/s11160-007-9057-7

2. Mahmood, N.; Khan, Y.S.A.; Ahmed, M.K. Hydrology of the Karnafully estuary with special reference to prawn and other larvae of economic importance. Final Report, Research Programme, University Grants Commission, Dhaka, Bangladesh, 1978; 33 pp.

3. DoF. Yearbook of Fisheries Statistics of Bangladesh, 2017-18. Fisheries Resources Survey System (FRSS), Department of Fisheries. Bangladesh: Ministry of Fisheries and Livestock: Dhaka, Bangladesh, 2018; 129 pp.

4. Hossain, M.S.; Das, N.; Sarker, S.; Rahaman, M. Fish diversity and habitat relationship with environmental variables at Meghna river estuary, Bangladesh. Egypt. J. Aquat. Res. 2012, 38, 213-226. https://dx.doi.org/10.1016/j.ejar.2012.12.006

5. Rahman, M.A.; Mandal, B.; Khamari, A.; Ullah, M.R.; Hoque, M.S.; Siddik, M.A.; Chakma, S. Ichthyofaunal diversity of Basurabad Beel in regards with threat factors and conservation measures, Bangladesh. Arch. Agric. Environ. Sci. 2019, 4(4), 478-487. https://dx.doi.org/10.26832/24566632.2019.0404015

6. Rahman, M.A.; Khamari, A.; Mandal, B.; Ullah, M.R.; Hossen, M.B.; Alam, M.A.; Saha, N. Assessment of Fish Biodiversity in Basuakhali Beel under Terokhada Upazilla, Khulna, Bangladesh. Asian J. Res. Biosci. 2019, 1(2), 55-64.

7. Angermeier, P.L.; Winston, M.R. Local vs regional influences on local diversity in stream. Ecol. 2015, 79(3), 911927. https://doi.org/10.1890/00129658(1998)079 [0911: LVRIOL]2.0.CO;2

8. Pielou, E.C. The measurement of diversity in different types of biological collection. J. Theor. Biol. 1966, 13, 131-144. https://doi.org/10.1016/0022-5193(66)90013-0

9. Vijaylaxmi, C.; Rajshekhar, M.; Vijaykumar, K. Freshwater fishes distribution and diversity status of Mullameri River, a minor tributary of Bheema River of Gulbarga District, Karnataka. Int. J. Syst. Biol. 2010, 2(2), 1-9. 
10. Islam, M.A.; Hossain, M.M.; Ahsan, M.E.; Nahar, A. Status and current worries of fish diversity in the Payra river, Patuakhali, Bangladesh. Int. J. Fish. Aquat. Stud. 2015, 2(3), 160-165.

11. DoF. Ilish Shampad Sangrakhan o Unnoun Babashthapona (In Bengli) (Hilsa resource conservation and development management), Fourth fisheries project, Department of Fisheries, Ministry of Fisheries and Livestock, Dhaka, Bangladesh. 2005.

12. Vyas, V.; Damde, V.; Parashar, V. Fish Biodiversity of Betwa River in Madhya Pradesh, India with special reference to a sacred ghat. Int. J. Biol. Conserv. 2012, 4(2), 71-77.

13. FishBase. List of fishes for Bangladesh. https:/www.fishbase.de/Country/ Country Checklist.php? what $=$ list\&trpp $=50 \& c \_c o d e=050 \&$ csub_code $=\&$ cpresence=present\&sortby $=$ alpha2\&vhabitat=all $2 \quad$ Access on September 5, 2019.

14. Palmer, C.M. Composite Rating of Algae Tolerating Organic Pollution. J. Phycol. 1969, 5, 78-82. https://doi.org/10.1111/j.1529-8817.1969.tb02581.x.

15. Saha, S.B.; Bhattacharya, S.B.; Choudhury, A. Diversity of Phytoplankton of Sewage Pollution Brackish Water Tidal Ecosystems. J. Environ. Biol. 2000, 21(1), 9-14.

16. Margalef, R. Perspectives in Ecological Theory. Chicago: University of Chicago PRESS. 1968.

17. Shannon, C.E.; Weaver, W.J. The Mathematical Theory of Communication. University of Illinois Press, Urbana. 1949; 117 pp.

18. Simpson, E.H. Measurement of diversity. Nat. 1949, 163, 688. https://doi.org/10.1038/163688a0.

19. Lad, D. Analysis of pollution status of wetland areas using various species diversity index. Scholars Acad. J. Biosci. 2015, 3(7), 616-617.

20. Staub, R.; Appling, J.W.; Hofstetter, A.M.; Haas, I.J. The effects of industrial wastes of Memphis and Shelby country on primary plankton producers. Biosci. 1970, 20, 905-912. https://doi.org/10.2307/1295583

21. Cunico, A.M.; Ferreira, E.A.; Agostinho, A.A.; Beaumord, A.C.; Fernandes, R. The effects of local and regional environmental factors on the structure of fish assemblages in the Pirapo' Basin, Southern Brazil. Landsc. Urban Plan. 2012, 105(3), 336-344. https://doi.org/10.1016/j.landurbplan.2012.01.002

22. Rowe, D.C.; Pierce, C.L.; Wilton, T.F. Fish Assemblage Relationships with Physical Habitat in Wadeable Iowa Streams. North Am. J. Fish. Manag. 2009, 29(5), 1314-1332. https://doi.org/10.1577/M08-192.1

23. Buisson, L.; Thuiller, W.; Lek, S.; Lim, P.; Grenouillet, G. Climate change hastens the turnover of stream fish assemblages. Glob. Change Biol. 2008, 14(10), 2232-2248. https://doi.org/10.1111/j.1365-2486.2008.01657.x

24. Ostrand, K.G.; Wilde, G.R. Temperature, dissolved oxygen, and salinity tolerances of five prairie stream fishes and their Role in explaining fish assemblage patterns. Trans. Am. Fish. Soc. 2001, 130(5), 742-749. https://doi.org/10.1577/15488659(2001)130<0742: TDOAST>2.0.CO;2

25. Dole-Olivier, M.J.; Malard, F.; Martin, D.; Lefe'bure, T.; Gibert, J. Relationships between environmental variables and groundwater biodiversity at the regional scale. Freshw. Biol. 2009, 54(4), 797-813. https://doi.org/10.1111/j.1365-2427.2009.02184.x

26. Bhatt, J.P.; Manish, K.; Pandit, M.K. Elevational Gradients in Fish Diversity in the Himalaya: Water Discharge Is the Key Driver of Distribution Patterns. PLoS ONE, 2012, 7(9), e46237. https://doi.org/10.1371/journal.pone.0046237 
27. Rathert, D.; White, D.; Sifneos, J.C.; Hughes, R.M. Environmental correlates of species richness for native freshwater fish in Oregon, U.S.A. J. Biogeogr. 1999, 26(2), 257-273. https://doi.org/10.1046/j.1365-2699.1999.00274.x

28. Jackson, D.A.; Peres-Neto, P.R.; Olden, J.D. What controls who is where in freshwater fish communities-the roles of biotic, abiotic, and spatial factors. Can. J. Fish. Aquat. Sci. 2001, 58(1), 157-170. https://doi.org/10.1139/f00-239

29. IUCN Bangladesh. Red List of Bangladesh Volume 1: Summary. IUCN. International Union for Conservation of Nature, Bangladesh Country Office, Dhaka, Bangladesh, 2015; xvi+122 pp.

30. Mohshin, A.B.M.; Haque, E. Diversity of Fishes of Mahananda river at Chapai Nawabgonj district. Res. J. Bio. Sci. $2009,4(7), 828-831$.

31. Chakraborty, B.K.; Mirza, M.A. Status of Aquatic Resources in Someswari River in Northern Bangladesh. Asian Fish. Sci. 2010, 23, 174-193.

32. Tongnunui, S.; Beamish, F.W.H.; Kongchaiya, C. Fish species, relative abundances and environmental associations in small rivers of the Mae Klong River basin in Thailand. Agric. Nat. Resour. 2016, 50(5), 408-415. https://doi.org/10.1016/j.anres.2016.09.001

33. Magurran, A.E. Ecological Diversity and Its Measurement. University Press, Princeton, NJ. 1988.

34. Nair, R.; Ittekkot, V.; Manganini, S.; Ramaswamy, V.; Haake, B.; Degens, E. T.; Honjo, S. Increased particle flux to the deep ocean related to monsoons. Nat. 1989, 338(6218), 749-751. https://doi.org/10.1038/338749a0

35. Hanif, M.A.; Siddik, M.A.B.; Chaklader, M.R.; Nahar, A.; Mahmud, S. Fish diversity in the southern coastal waters of Bangladesh: present status, threats and conservation perspectives. Croat. J. Fish. 2015, 73, $148-161$.

36. Nabi, M.R.U.; Mamun, M.A.A.; Ullah, M.H.; Mustafa, M.G. Temporal and Spatial Distribution of Fish and Shrimp Assemblage in the Bakkhali River Estuary of Bangladesh in Relation to Some Water Quality Parameters. Mar. Biol. Res. 2011, 7(5), 436-452. https://doi.org/10.1080/17451000.2010.527988

37. Rahman, M.A.; Iqbal M.M.; Islam, M.A.; Barman, S.K.; Mian, S.; Das, S.K.; Hossain, M.M. Physicochemical parameters influence the temporal and spatial distribution of catfish assemblages in Kushiyara River, Bangladesh. Bangladesh J. Fish. 2018, 30(1), 61-72.

38. Huh, S.H.; Kitting, C.L. Trophic relationships among concentrated populations of small fishes in seagrass meadows. J. Exp. Mar. Biol. Ecol. 1985, 92(1), 29-43. https://doi.org/10.1016/0022-0981(85)90020-6

39. Keskin, Ç.; Ünsal, N. The Fish Fauna of Gökçeada Island, NE Aegean Sea, Turkey. Ital. J. Zoo. 1998, 65, $299-302$.

40. Ryer, C.H.; Orth, R.J. Feeding ecology of the northern pipefish, Syngnathus fuscus, in a seagrass community of the lower Chesapeake Bay. Estuar. 1987, 10(4), 330. https://doi.org/10.2307/1351891

41. Alam, M.S.; Hossain, M.S.; Monwar, M.M.; Hoque, M.E. Assessment of fish distribution and biodiversity status in Upper Halda River, Chittagong, Bangladesh. Int. J. Biodivers. Conserv. 2013, 5(6), 349-357.

42. Whitfield, A.K. Ichthyoplankton in a Douthern African surf zone: Nursery area for the post larvae of estuarine associated fish species? Estuar. Coast. Shelf Sci. 1989, 29, 533-547. https://doi.org/10.1016/0272-7714(89)90009-7

43. Loneragan, N.R.; Potter, I.C. Factors influencing community structure and distribution of different life-cycle categories of fishes in shallow waters of a large Australian estuary. Mar. Biol. 1990, 16, $25-37$. https://doi.org/10.1007/bf02114671 
44. Young, G.C.; Potter, I.C. Do the characteristics of the ichthyoplankton in an artificial and a natural entrance channel of a large estuary differ? Estuar. Coast. Shelf Sci. 2003, 56, 765-779. https://doi.org/10.1016/s0272-7714(02)00300-1

45. McErlean, A.J.; O'Connor, S.G.; Mihursky, J.A.; Gibson, C.I. Abundance, diversity and seasonal patterns of estuarine fish populations. Estuar. Coast. Mar. Sci. 1(1), 19-36. https://doi.org/10.1016/0302-3524(73)90054-6

46. Blaber, S.J.M. Tropical Estuarine Fishes: Ecology, Exploitation and Conservation, Blackwell Science, Oxford, 2000; $372 \mathrm{pp}$.

47. Cyrus, D.P.; McLean, S. Water temperature and the 1987 fish kill at Lake St Lucia on the South Eastern coast of Africa. South. Afr. J. Aquat. Sci. 1996, 22(1-2), 105-110. https://doi.org/10.1080/10183469.1996.9631377

48. Pramila, k.; Sharda, D.; Chaudhari, P.R.; Wate, S.R. A Biomonitoring of Plankton to Assess Quality of Water in the Lakes of Nagpur City. The 12th World Lake Conference, 2008; 160-164 pp.

49. Craig, J.F.; Halls, A.S.; Barr, J.J.F.; Bean, C.W. The Bangladesh floodplain fisheries. Fish. Res. 2004, 66(2-3), 271-286. https://doi.org/10.1016/S0165-7836(03)00196-6

50. Spillmann, R.K.; Bachler, G. Environment and Conflicts Project, ENCOP Occasional Papers. Center for Security Studies. Swiss Peace Foundation. Berne, 1993; 95 pp.

51. Zalinge, N.; Nuov, S.; Ounsted, R.; Sopha, L. Status of the Cambodian inland capture fisheries sector with special reference to the Tonle Sap Great Lake. In Cambodia Fisheries Technical Paper Series, vol. III, ed. van Zalinge N., Nuov S., Ounsted R., and Sopha L., 233 pp. Cambodia: Inland Fisheries Research and Development Institute. 2001.

52. Sultana, M.A.; Mazumder, S.K.; Kunda, M. Fishing Gears and Crafts Used in Payra River, Bangladesh. Eur. J. Appl. Sci. 2016, 8(6), 337-346.

53. Saha, J.K.; Hassan, M.R.; Habib, M.A.B.; Ali, M.M. Impact on fishers and gears on biodiversity of fish and prawn in Gawha beel, Nawabgonj, Bangladesh. BAU, Mymenshingh, Bangladesh Food and Agricultural Organization of the UN. Rome, Italy. 2005.

54. Parveen, S.; Faisal, I.M. People versus power: the Geopolitics of Kaptai Dam in Bangladesh. Int. J. Water Resour. Dev. 2002, 18, 197-208. https://doi.org/10.1080/07900620220121756 